\title{
A representação de imagens no acervo da Biblioteca Digital Paulo Freire - proposta e percursos
}

\author{
Carlos Xavier de Azevedo Netto \\ Doutorado em ciência da informação. Universidade \\ Federal do Rio de Janeiro, UFRJ. \\ E-mail: carlosxavier@ccsa.ufpb.br \\ Bernardina Maria Juvenal Freire \\ Mestre em ciência da informação, CMCI- \\ UFPB. Bibliotecária - DBD-UFPB. \\ Professora do Departamento de Biblioteconomia \\ e Documentação da UFPB. \\ E-mail: bernardinafreire@yahoo.com.br \\ Perpétua Pereira \\ Estagiária do projeto. Bolsista da CEAD. \\ Graduanda em bilbioteconomia da UFPB. \\ E-mail: pepecj20@bol.com.br
}

\section{Resumo}

O presente trabalho apresenta os resultados obtidos no projeto Identificação e Análise de Imagem para Formação de um Sistema de Representação e Recuperação da Informação, financiado pela Coordenação Institucional de Ensino a Distância da UFPB, que visa à elaboração de princípios de representação da informação imagética do acervo da Biblioteca Digital Paulo Freire, com o intuito de formar uma política de representação para a informação de natureza imagética. Para sua execução, contou-se com os pressupostos teóricos da semiótica, estética e teoria da arte, bem como subsídios da teoria da representação. Como resultados o presente trabalho aponta as possiveis formas de representação das imagens e sua incorporação ao acervo informacional da Biblioteca Digital Paulo Freire.

Palavras-chave

Representação; Imagem; Semiótica; Acervo imagético.

\section{Image representation in Paulo Freire Digital Library Collection - proposal and routes}

\begin{abstract}
The objective of this paper is to present the results obtained on the project Identification and Analysis of Image for Development of an Information Recovery and Representation System, which was financed by the Institutional Coordination for Distance Education. The project purposes the elaboration of representation principles of imagetic information in Paulo Freire Digital Library collection. To support its execution, the theoretical conjectures of semiotics, art theory and aesthetic were considered, as well as subsidies of representation theory. The present paper points out image representation aspects and its incorporation into the informational collection of Paulo Freire Digital Library.
\end{abstract}

Keywords

Representation; Image; Semiotics; Imagetic collection.

\section{INTRODUÇÃO}

Na atualidade, o universo imagético vem ocupando lugar de destaque na sociedade contemporânea, justamente por ser, reconhecidamente, um dos principais recursos cognitivos. No campo da comunicação de massa, conforme é apresentado por Moles (1982) e por Benjamin (1982), a visualidade é que faz com que a obra-de-arte maximize o seu potencial estético, dentro da experiência humana. Com a instauração de um novo paradigma do conhecimento, a imagem passa a ser tratada como um significativo repositório de informações que antes passava despercebida. Nessa ótica, a informação inerente ao universo imagético começa a ser incorporada pelo paradigma estético (Guattari, 1998) emergente. Com isso, o potencial de informação que dispõe está:
Além da própria natureza complexa do objeto imagético, as diferentes possibilidades de uso desse registro, que podem ir da mera ilustração de textos, passar pela importância como fonte de informações para diversas áreas do conhecimento, até o deleite absoluto da pura fruição estética, encanta e apaixona aqueles que se dedicam em conhecê-lo (Silva, 2000, p. 169).

A partir dessa realidade, as várias naturezas que a informação assume têm propiciado, no decorrer da história, necessidades específicas de seu tratamento, ordenação e documentação, sempre em instâncias especializadas de armazenamento do conhecimento (bibliotecas, arquivos, museus etc.). Com o advento das novas tecnologias da informação e da comunicação, ocorre uma diluição das fronteiras entre essas instâncias, confluindo documentos de naturezas das mais diversas para um mesmo acervo.

Esse é o caso da Biblioteca Digital Paulo Freire, que reúne, em seu acervo, documentação de origem impressa, sonora, imagética e virtual acerca da vida e obra de Paulo Freire. $O$ projeto de construção dessa biblioteca digital assumiu, em seu desenvolvimento, o ônus da diversificação da noção de documento com que ia se defrontar e tratar. Assim, surge a necessidade de uma gama maior de instrumentos, práticos e teóricos, para o tratamento da informação nos mais variados suportes e naturezas. 
O conjunto dessas informações, além de se preocupar com a divulgação dos princípios educacionais de Paulo Freire, carrega em si o sentido da memória. Memória essa ligada a toda uma corrente de pensamento da educação brasileira e, ao mesmo tempo, marcadamente ligada a momentos sociopolíticos de extrema relevância no cenário nacional e internacional. Nesse prisma, a questão da memória passa a ser vista pela ótica da coletividade, assumindo que:

A questão fundamental continua sendo a dos atributos da memória. Todos sabiam que uma memória não se molda necessariamente a uma ordem cronológica, que ela pode ser irruptiva, projetiva, confusa, contraditória... As funções culturais das memórias ditas coletivas não correspondem senão a uma maneira possível, dentre outras, de estabelecer uma ordem dinâmica de traços mnêmicos. (...)

A memória não deixa de brincar com a identidade, embora mantenha um pacto com ela. Para quem quer que seja, o interesse conferido à lembrança só se torna princípio de satisfação na confusão das evocações nesse emaranhado que chama outras lembranças, ainda que a busca da verdade ou da autenticidade seja a sua finalidade aparente (Jeudy, 1990, p. 19).

Partindo dos contornos que se têm da instituição "Biblioteca", é possível considerá-la como uma das instâncias de preservação de elementos constitutivos de memórias coletivas. Partindo dessa visão, nota-se que uma das justificativas do presente projeto reside no fato de prover instrumentos de perpetuação das imagens, com isso consolidando partes importantes pertencentes à memória nacional, já que a própria imagem de Paulo Freire é um dos referentes dessa memória coletiva.

A outra justificativa que se apresenta para esse projeto é de cunho mais técnico e pragmático. Está voltada aos procedimentos para a sistematização do tratamento e recuperação das informações imagéticas encontradas no acervo dessa instituição de memória, a Biblioteca Digital Paulo Freire. Como há demanda de documentação imagética de considerável montante, há a necessidade de construção de um corpus teórico-metodológico que dê conta dessa documentação peculiar. Assim, o presente projeto se justifica, tanto no aspecto ideacional, como instrumento de preservação de memória, quanto na dimensão prática, no fornecimento de condições que fundamentem a construção de instrumentos de representação e recuperação dessa informação particular.

\section{IMAGEM: DISCUSSÃO CONCEITUAL}

O termo imagem tem sua origem na expressão latina imago, como a máscara mortuária utilizada pelos romanos.
Pode-se considerar que esse termo possui em si um sentido polissêmico, por permitir um leque muito diverso de significados, desde reflexo, passando por sombra, por simulacro, até as imagens mentais, ou signos. Sua existência está sempre ligada a uma determinada áurea, podendo ser religiosa, mística, como réplica ou como simulação (na atualidade).

A imagem, portanto, tem perpassado todos os campos do conhecimento humano, desde o religioso, até o científico. No campo religioso, essa entidade é vista como uma forma de representação da alma de um morto ou como instrumento de reflexão racional, mas entendimento da imagem se desdobra de uma outra forma no terreno dogmático das religiões. Na mitologia de muitas religiões, a imagem é portadora de um caráter divino e por isso núcleo de embates e interdições. Nas religiões judaicocristãs a imagem manifesta uma ação sobre os homens, sendo a sua interdição um dos preceitos fundamentais da mitologia bíblica, que a torna extremamente forte e perigosa. Isso pode ser observado a partir da negação da imagem, como ocorre na iconografia islâmica, que se concentra no geometrismo em detrimento de temas figurativos. O questionamento sobre a natureza divina das imagens também está presente na história do Ocidente: a proibição do culto e discriminação de imagens durante o Império Bizantino, nos séculos VIII e IX, ou ainda, já na Idade Moderna, o iconoclasmo imposto pela Reforma Protestante, que, opondo-se à idolatria, pregava a volta restrita às escrituras sagradas, como pode ser entendido no desenvolvimento histórico da arte delineado por Hauser (1972).

Além de na religião, a imagem está presente nos campos das artes. Nesse campo em particular, a imagem assume um destaque especial, advindo da própria natureza estética que esse conceito assume. Essa natureza estética fica clara nas artes plásticas (pintura escultura), na arquitetura, já que se formam diretamente sobre imagens, dentro de uma estética culturalmente determinada. Em outras expressões artísticas, a imagem assume uma importância primordial, quer na hora que os personagens assumem e constroem o espaço do palco, como no teatro, quer na hora em que o leitor constrói imagens a partir de um texto, como na literatura. Mas:

a noção de imagem vincula-se estritamente à representação visual: afrescos, pinturas, mas também iluminuras, ilustrações decorativas, desenho, gravura, filme, vídeo, fotografia e até imagens de síntese (Joly, 1996, p.18).

Enquanto no campo científico (medicina, astronomia, matemática, meteorologia, física etc.), sob uma outra ótica, 
a imagem está relacionada à "visualização de fenômenos" (Joly, 1996, p.23). Para a autora, as imagens científicas são formadas basicamente por dois tipos distintos: imagens "verdadeiras" ou "reais" e imagens resultantes de simulações numéricas. As primeiras são imagens que ajudam a observar e a interpretar a realidade a partir do seu registro físico. Ecografia, que registra ultra-sons, scanners a laser, raios $\mathrm{x}$, dentre de outros dispositivos óticos e fotográficos que registram e ampliam nosso universo visual tanto no domínio pequeno (microfotografia), quanto no infinitamente grande (astrofotografia). Na física molecular, uma fotografia tirada em uma câmera de nuvem permite visualizar a trajetória de uma partícula. No plano macro, as fotografias de satélites supervisionam os fenômenos meteorológicos, as transformações ambientais etc.

$\mathrm{Na}$ atualidade, observa-se o problema da associação direta entre as mídias eletrônicas e a imagem, como foi apontado por Joly (1996). Para essa autora, os sentidos dados atualmente pela imagem associam-na diretamente com as mídias eletrônicas, principalmente com a televisão e a propaganda, quando assinala que

\section{(...) o vertiginoso apanhado das diferentes utilizações do termo 'imagem' lembra-nos o deus Proteu: parece que a imagem pode ser tudo e seu contrário - visual e imaterial, fabricada e 'natural', real e virtual, móvel e imóvel, sagrada e profana, antiga e contemporânea, vinculada à morte, analógica, comparativa, convencional, expressiva, comunicativa, construtora e destrutiva, benéfica e ameaçadora (Joly, 1996 p.27)}

Onde:

O emprego contemporâneo do termo 'imagem' remete, na maioria das vezes, à da mídia. Anunciada, comentada, adulada ou vilipendiada pela própria mídia, a "imagem" torna-se então sinônimo de televisão e publicidade (Joly, 1996 p. 14).

A conceituação de imagem deve ser considera diversa, não só pela natureza diferenciada de suas mídias, mas pelos modos distintivos de apresentação, permanência e ação. No caso do acervo imagético da Biblioteca Digital Paulo Freire (BDPF), ele está delimitado por imagens de origem química, como as fotografias, e as de origem magnética, como das fitas de vídeo, tratando de temáticas ligadas diretamente à vida, ação e obra do educador Paulo Freire. Assim, a noção que se adota no presente projeto é aquela que restringe a imagem ao acervo mencionado, como os registros, dentro da esfera da estética (ou da forma), de ações e eventos, de quaisquer origens ou suportes sobre a temática principal da BDPF.

\section{INFORMAÇÃO IMAGÉTICA}

A imagem assume várias funções no decorrer da história humana assumindo contornos socioculturais distintos de acordo como essa função. Para ilustrar essas várias funções, tomo emprestadas as categorias proposta por Jacque Aumont (1995), segundo as quais a imagem é submetida a três principais modos de funções distintas: o simbólico, o epistemológico e estético.

Como modo simbólico da imagem é o visto pelas representações religiosas e rituais que sempre estiveram presentes na história humana, desde as cavernas de Lascaux e Altamira, passando pelos afrescos da antiguidade, pelas imagens das culturas clássicas até as imagens do catolicismo, primitivo, medieval ou contemporâneo. Uma sucessão de imagens, com estéticas, suportes e veiculações diferenciadas, está marcando definitivamente a história do homem. Mas não só no tempo, as diversas formas de conceber e produzir as imagens têm sido marcadas por um processo de simbolização, em que se estabelece maior ou menor relação com o objeto simbolizado.

No modo epistêmico, a imagem traz informações visuais sobre o mundo, tornando-se um instrumento de conhecimento. Através das iluminuras, pranchas botânicas, fotografias de expedições ou mapas, a imagem fornece informações sobre os objetos, os lugares ou as pessoas. Também para Gombrich (1995), a imagem exerce uma função epistemológica na medida em que ela não é uma reprodução da realidade, mas um resultado de um longo processo, durante o qual são utilizados alternadamente esquemas e correções. Sua construção vai ser influenciada por todo um conjunto de determinantes socioculturais que compõe o repertório sígnico, tanto do seu produtor, quando da audiência para quem essa imagem é produzida.

Sobre o modo estético da imagem, Aumont (1995) aponta para as "sensações (aisthesis) específicas" que esse tipo de imagem proporciona em seu espectador, lembrando ainda que

(...) essa função da imagem é hoje indissociável, ou quase, da noção da arte, a ponto de se confundir as duas, e a ponto de uma imagem que visa obter um efeito estético pode se fazer passar por uma imagem artística (vide a publicidade, em que essa confusão atinge o auge) (Aumont, 1995, p.80-81).

A noção de imagem, portanto, desencadeia variações múltiplas de funções e significados. Para evitar uma confusão mental, este estudo adota um núcleo comum que integra todas essas significações, conceituando a imagem como um artefato que intercede a relação do 


\section{Carlos Xavier de Azevedo Netto / Bernardina Maria Juvenal Freire / Perpétua Pereira}

homem consigo próprio e com o mundo a sua volta, como modo de produção de sentido.

Na mesma direção, quando Santaella e Nöth (1998), de um lado, organizam a complexidade de tipos de imagens, dividindo-as em dois domínios principais - o domínio das imagens perceptíveis e o domínio das imagens mentais -, do outro, contrapõem a essa divisão através de "conceitos unificadores de signo e representação". Para a autora, é pelo conceito de representação que o domínio das representações visuais que chegam por meio dos sentidos (pinturas, gravuras, desenhos, fotografia etc.) interligamse ao domínio imaterial das imagens.

Não há imagens como representações visuais que não tenham surgido de imagens na mente daqueles que a produziram, do mesmo modo que não há imagens mentais que não tenham alguma origem no mundo concreto dos objetos visuais (Santaella e Nöth, 1998, p.13).

Assim, a noção de imagem como representação nos interessa porque cria um vínculo comum entre todos os tipos de imagens até aqui expostas, precisando o termo imagem como algo que produz significados, isto é, interpretações na mente daquele ou daqueles que a percebe, tomando alguns traços emprestados do real, o qual por sua vez torna a ser revestido de novos sentidos pelo processo pela interpretação mental, gerando, como uma cadeia infinita, novos traços do real para constituição de novas imagens. Sobre esse ciclo infinito de significação, Umberto Eco afirma:

Esta contínua circularidade é a condição normal da significação, e é isto que permite o uso comunicativo dos signos para referir-se a coisas. Refutar como teoricamente insatisfatória essa situação significa apenas que não se compreendeu qual seja o modo humano de significar, o mecanismo através do qual se fazem a história e a cultura, o modo mesmo pelo qual, definindo-se o mundo, se atua sobre ele, transformando-o (Eco, 1980, p.60).

Portanto, no âmbito desta pesquisa, a imagem é entendida como um fenômeno de significação e de comunicação e, como tal, pode será abordada como conteúdo de atividade semiótica.

Considerando a imagem como um ato de representação, já que "o texto representa o objeto por convenção, enquanto a imagem o representa por projeção" (Smit, 1996, p.30), assumindo-se diferentes níveis de construção de significados, ou até mesmo como criação, como é abordado por Lucena (2002) para a construção das imagens virtuais. Nesse sentido a imagem pode ser abordada a partir de diferentes níveis de análise. Esse níveis analíticos estão diretamente relacionados à natureza e à abrangência da informação pretendida. Para tanto, recorreu-se a Panofsky (1979), que distingue os níveis informacionais da imagem em:

- Nível Pré-iconográfico - entendido como o nível em que se dá a descrição da imagem em seus atributos constitutivos;

- Nível Iconográfico - entendido como o reconhecimento e/ou estabelecimento da significação da imagem;

- Nível Iconológico - entendido como o relacionamento entre os significados construídos e a contextualização da imagem e de seu interprete.

Com isso, parafraseando Smit (1996), a imagem pode ser considerada uma tríade em sua abordagem histórica, a qual, em um primeiro momento, passa a ser um espelho do real, considerada a seguir como uma transformação do real e, na atualidade, como traço do real. Essa categorização leva a imagem a se aproximar das categorias do signo peirceano, cujo primeiro momento estaria próximo da noção de ícone para, a seguir, aproximar-se da noção de símbolo e, por fim, a noção de imagem índice. Considerando a fotografia como imagem,

O conceito da fotografia-índice parece muito promissor para a documentação. Ele deve determinar os parâmetros de tratamento documentário da imagem fotográfica, visando à sua representação, pelas seguintes razões:

a) preserva a polissemia da imagem, ao rejeitar (ou realmente minimizar) sua leitura enquanto símbolo (...), por mais correta que seja, direciona ou determina a leitura e a conseqüente reutilização da imagem, empobrecendo-a;

b) afirma a existência de um documento, no qual o referente se faz muito presente, mas que não se confunde com este, como o proposto pelo conceito de fotografia-ícone (Smit, 1996, p. 30).

A informação imagética contida no acervo da BDPF pode ser entendida a partir da categorização elaborada por Azevedo Netto (1998) a respeito da informação contida nos painéis de arte rupestre. Essa analogia está dada pelo fato de as manifestações estáticas promovidas pelos grupos humanos pré-históricos possuírem uma natureza iconográfica, muito próxima das imagens produzidas hoje em dia, quer por meios químicos, físicos ou até digitais. As informações podem ser consideradas como informações técnicas, no que diz respeito às técnicas utilizadas para a confecção de determinadas imagens, as informações estéticas, que 
dão conta das formas e temáticas que compõem cada imagem, a informação espacial, que identifica o espaço onde a imagem foi capturada ou sobre o qual foi produzida e, por fim, a informação relacional, que leva em conta os fatores de relação entre a imagem em si, a partir de seus elementos constitutivos, e demais conjunto de atributos que podem ser inferidos, tais como a cronologia.

Considerando a imagem uma "entidade tripartida" (SmiT, 1996, p. 34), para exercer as funções de representação e veículo informacional, ela deve ser composta de suporte, expressão imagética e conteúdo informacional. Como suporte, entendem-se, no presente estudo, a superfície e a técnica pela qual a imagem foi produzida, química, magnética ou digital. Como expressão imagética, está a composição da imagem em si, os seus elementos constitutivos e as relações que estabelecem entre si no espaço da imagem. E, como conteúdo informacional, as formas de interpretação das imagens, tais como a identificação individual dos elementos de sua composição, quer personagens, espaços, contextos sociais etc.

No caso específico do acervo imagético da BDPF, os termos a serem utilizados serão incorporados de acordo com os atributos que o acervo apresentar. Para a identificação desses atributos, recorreu-se ao trabalho de Smit (1996), que aponta algumas características básicas a serem observadas em uma imagem, tomando-se por base o seu nível de informação estética e relacional e alguns princípios apontados por Silva (2002), para a preservação e conseqüente memória coletiva acerca das imagens. Essas categorias foram dividias em dois grupos principais, que devem ser abordados em momentos diferentes da representação. $O$ primeiro grupo é o de atributos genéricos acerca da imagem, e o segundo, dos atributos específicos de cada imagem, individualizando cada uma de suas ocorrências. Sendo que a primeira abordagem a ser utilizada vai ser baseada diretamente da sua representação genérica. Para tanto, procurou-se o estabelecimento de temáticas gerais sobre o universo encontrado, assinalando que as mesmas são proposições que devem ser testadas e adequadas à própria dinâmica do acervo imagético.

\section{PRINCÍPIOS DA REPRESENTAÇÃO IMAGÉTICA NA BDPF}

Como princípio geral para o tratamento documental da informação imagética da BDPF, buscaram-se elementos que permitissem representar as informações potenciais em suporte imagético. Para tanto, em busca de uma coerência interna entre os mecanismos de representação, adotouse a formatação oriunda do Brased, que é o Thesaurus Brasileiro de Educação, criado em 1980, reunindo assim um conjunto de conceitos, relacionados com a área de educação, para construção de um vocabulário controlado de termos para busca e recuperação da informação. Esse thesaurus foi elaborado a parti da análise crítica da realidade educacional e seu contexto, em especial no Brasil, conforme registra o site do Inep.

A base conceitual de construção do thesaurus está fundamentada nos princípios da educação em seu contexto global e interdisciplinar, que é dada por uma matriz conceitual. A sua matriz é composta por quatro campos que definem a sua abrangência para área de educação, centrando-se no homem como núcleo e razão da prática educativa. Nessa matriz está contido ainda um campo que relaciona os conceitos definidos nos campos anteriores, que se tornam descritores das informações desejadas. Esses quatro campos, de acordo com o Brased, são:

- 100 - Contexto da Educação - A educação do homem se realiza dentro da realidade global e em interação com esta; fora desta não há educação;

- 200 - Escola como Instituição Social - a escola é a educação institucionalizada; na sociedade politicamente organizada, de fato, encontraremos todas as condições para que a educação do homem socialmente aconteça;

- 300 - Fundamentos de Educação - a educação é o principal processo do desenvolvimento humano, que é pluri e interdisciplinar, isto é, muitas ciências fundamentam e integram no processo e a ação educativos;

- 400 - Educação: princípios, conteúdo e processo - o homem evolui interagindo constantemente com o meio: é a educação propriamente dita com seus princípios, conteúdo e processo.

Com fundamentação na abordagem proposta por Becker (1993), a proposta de metodologia empregada para representação do acervo imagético da BDPF teve como ponto central a sua flexibilidade, com o intuito da constante adequação do método às peculiaridades e contornos que o objeto de estudo assume no decorrer do processo de pesquisa. Então, esta proposta metodológica não se pretende mostrar acabada, mas em início de construção, a ser desenvolvida com os subsídios obtidos por instrumentos teóricos da ciência da informação, da semiótica, teoria da representação e do conceito. Sua fundamentação teórica encontra respaldo, principalmente, nos trabalhos de Peirce (1985), Santaella; Nöth (1998), Eco (1980 e 1991), Guattari (1998) e Fischer (1987).

O embasamento metodológico deste trabalho, conforme mencionado, tem como um de seus pilares a teoria 


\section{Carlos Xavier de Azevedo Netto / Bernardina Maria Juvenal Freire / Perpétua Pereira}

semiótica, elaborada por Peirce (1985), que sua figura mais importante, para o presente objetivo - o interpretante, que é visto como a instância onde há a construção do significado, da recuperação da informação. E esse significado, ou informação, somente é alcançado pelo processo de semiose ilimitada (ECO, 1980, p.60), uma vez que:

\section{[...]ela nos mostra como a significação (e a comunicação), por meio de deslocamentos contínuos que referem um signo a outros signos ou a outras cadeias de signos, circunscreve as unidades culturais de modo assintótico, sem conseguir jamais "tocá-las" diretamente, mas tornando-as acessíveis através de outras unidades culturais. Desse modo, uma unidade cultural nunca precisa ser substituída por algo que não seja uma entidade semiótica [...] A semiose explica-se por si só.}

Esta contínua circularidade é a condição normal da significação e é isto que permite o uso comunicativo dos signos para referir-se às coisas.

Para que a recuperação da informação se efetive, é importante que o receptor/usuário dessa informação disponha de elementos que permitam a manipulação dos conceitos que definem as representações das imagens, isto é, que o receptor esteja interligado conceitualmente com a esfera documental dessas imagens. Para o entendimento dos conceitos que compõe determinada imagem, recorrese ao que foi definido dentro da ciência da informação como "análise de conceitos".

Entendendo que a relação entre a linha teóricometodológica adotada no trabalho e os processos de representação se faz pela análise e crítica desses processos, a identificação e análise desse processo são fundamentais, de acordo com Dahlberg (1978-a, 1978-b), para a análise de conceitos, e em Hjorland e Albrechtsen (1995), para a análise de domínio. A construção dessas representações também levará em conta o que são consideradas informação central, marginal e pseudo-informação, em uma relação ao que foi discutido por Jaenecke (1994), sobre o conhecimento. As representações aqui consideradas são aquelas denominadas de conceitos, enquanto unidade de conhecimento (Dalhberg, 1978). Essa análise estará voltada à localização dos elementos que fundamentam as representações e seus graus de relevância para essas mesmas representações, em comparação com o que está delimitado pelo acervo da Biblioteca Digital Paulo Freire.

A teoria do conceito é aquela que procura dar conta das formas de surgimento, definição e uso dos conceitos, enquanto unidades representacionais originárias na esfera do real. Todo conceito é referido por um objeto, quer ele seja individual - entendido como aquele objeto único dentre os demais, constituindo-se em unidade, situados no tempo e no espaço - quer ele seja geral - aqueles que estão fora do tempo e do espaço, representando uma categoria de objetos que possuam um ou mais atributos em comum - e que teriam como paralelo na arqueologia a noção de tipo. Mas, para o estudo e entendimento das formas de transferência da informação dentro de uma mesma comunidade científica, os conceitos considerados aqui são aqueles que estão fora da esfera da representação individual, sendo aqueles que estão afeitos a unidades mais amplas, capazes de definir as unidades individuais. No que se refere à sua origem, pode-se definir a formação de conceitos como:

[...] a reunião e compilação de enunciados verdadeiros a respeito de determinado objeto. Para fixar o resultado dessa compilação necessitamos de um instrumento. Este é construído pela palavra ou por qualquer signo que possa traduzir em fixar essa compilação. É possível definir, então, o conceito como compilação de enunciados verdadeiros sobre determinado objeto, [...] (Dahlberg, 1978-b, p. 102).

Em seguida, será elencado o acervo imagético que está depositado na Biblioteca Digital Paulo Freire, procurando equacionar uma tipologia desses documentos. Ressaltase, aqui, que a proposição desses atributos tem caráter meramente tentativo, e com certeza sofrerão alterações, quer de inclusão, quer de exclusão de outros atributos no decorrer da implementação dos trabalhos. Para tanto, será elaborada uma hierarquia tentativa de atributos para a categorização das imagens, obedecendo à seguinte ordenação: suporte; cor; tecnologia; cronologia; localização; conservação.

Por suporte, entende-se o tipo de superfície em que se encontra o registro imagético. Por cor, quais as cores que a imagem apresenta, se é um positivo ou um negativo, e sua situação. Por tecnologia, entende-se o aparato tecnológico para captação/criação da imagem (fotografia, cinema, vídeo etc). Por cronologia, considera-se a época em que o registro foi realizado, no caso de original, e a época em que foi realizada a cópia, para os casos de registros não originais. Por localização, entende-se o local onde o registro foi produzido e sobre qual local foi registrado. E, por conservação, fica entendido o estado em que se encontra o registro no momento de sua catalogação.

Com a relação dos atributos tipológicos realizados, iniciase o levantamento do acervo informacional passível de ser encontrado nessas imagens e os instrumentos que podem ser empregados para a sua recuperação. Isso será realizado utilizando-se as noções de classificação apresentadas por Piedade (1977), em especial a facetada discutida por Langridge (1977). 
Para a construção de um sistema que possibilite a recuperação dessas informações, será utilizado como fundamento metodológico o que está apresentado por Foskett (1973), no que caracteriza um sistema de recuperação de informação. Essa fundamentação não delimita a amplitude e configuração do sistema, mas, antes, fornece os princípios de constituição de um sistema especializado, como foi abordado por Alves e Valério (1998). Deixa-se claro, porém, que, de acordo com os contornos assumidos pelo acervo imagético da Biblioteca Digital Paulo Freire, algumas adaptações e modificações deverão fazer parte da proposta de sistema a ser apresentada, já que todo o instrumental metodológico deve ser construído e estar em consonância com o seu objeto de estudo (Becker, 1993).

\section{PROPOSTA DE ABORDAGEM}

No processo de indexação das fontes imagéticas da Biblioteca Digital Paulo Freire, consideraram-se, na medida do possível, os princípios da indexação, procurando agrupar os elementos semelhantes, extraindo deles os descritores que representam seus conteúdos. Entende-se por descritores os termos ou palavras que representam o conteúdo das imagens para compor um determinado índice, favorecendo a seleção dos termos por parte do usuário da informação.

O trabalho originou-se com o projeto Identificação e Análise de Imagem para Formação de um Sistema de Representação e Recuperação da Informação, que teve como início o levantamento bibliográfico nas Bibliotecas Central e Setorial da Universidade Federal da Paraíba, sobre o tema Imagem, relacionando-o à análise, indexação e tratamento das imagens com vistas à recuperação e representação da informação.
Em seguida, observou-se a classificação em séries, ordenação temática em linguagem natural, respondendo às seguintes categorias:

- Pessoal $\rightarrow$ imagens em pixel que remetem ao âmbito familiar (Ps);

- Documental $\rightarrow$ imagens em pixel que mostram fatos relacionados a entrevistas e palestras (Dc);

- Política $\rightarrow$ imagens em pixel que revelam relações políticas e /ou presença de políticos (Pl);

- Homenagem $\rightarrow$ imagens em pixel que representam homenagens $(\mathrm{Hm})$;

- Diplomação $\rightarrow$ imagens que registram cerimônias de diplomação $(\mathrm{Dp})$;

- Atuação Pedagógica $\rightarrow$ imagens em pixel que revelam a atuação pedagógica de Paulo Freire (AP).

Para fins de identificação e localização, adotou-se um código alfa-numérico A referida notação constituise do formato da imagem e do número de entrada do escaneamento digital da imagem, conforme representado no exemplo abaixo:

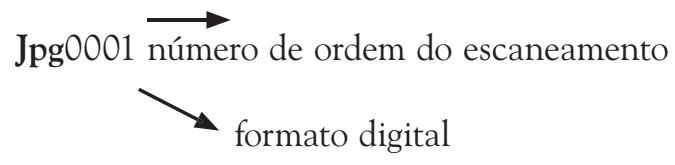

Como complemento às informações, esse instrumento traz uma descrição dos principais conteúdos constantes dos documentos imagéticos propiciando, de forma clara e objetiva, maior rapidez na consulta por parte

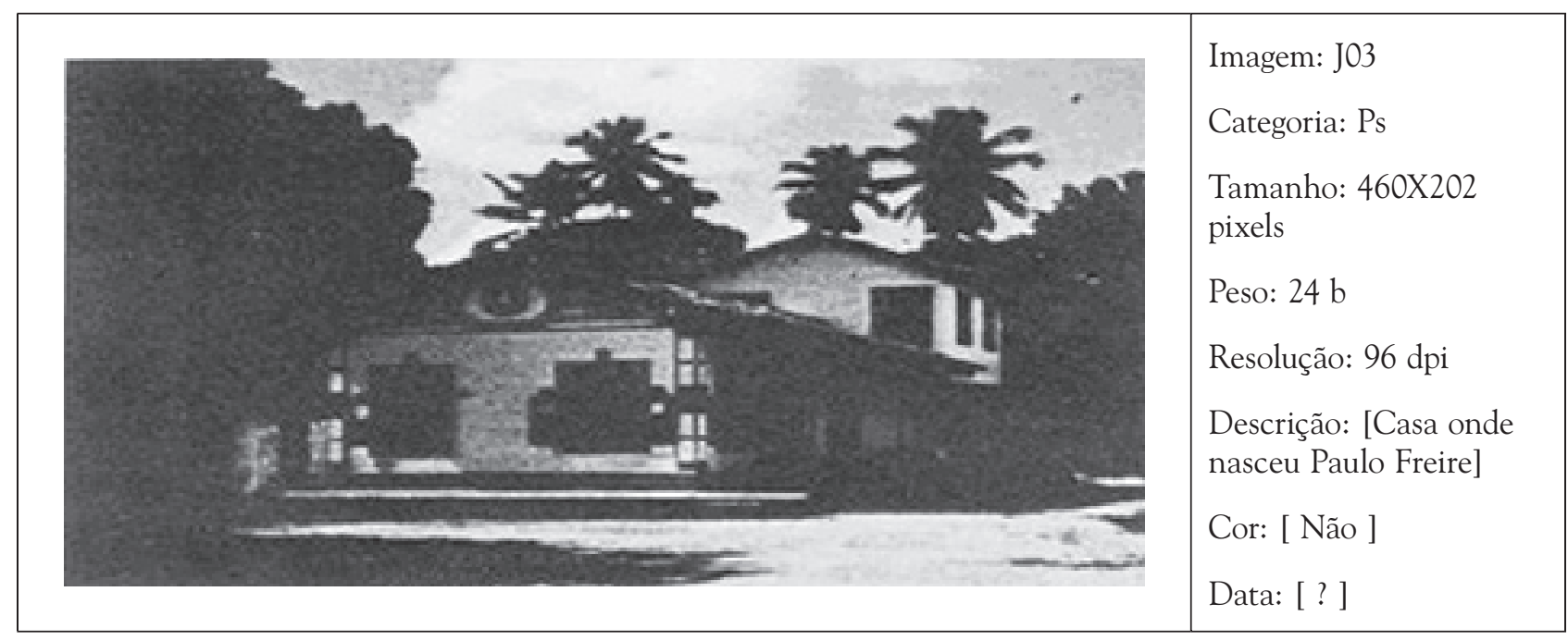




\section{Carlos Xavier de Azevedo Netto / Bernardina Maria Juvenal Freire / Perpétua Pereira}

do pesquisador, além de fornecer o local (espaço), a data e algumas informações que julgamos pertinentes. Para caracterizar essas informações, adotamos algumas abreviaturas, tais como:

$\Rightarrow$ Formato da Imagem - Jpg

$\Rightarrow$ Tamanho da Imagem - Pixel

$\Rightarrow$ Peso da Imagem KiloByte $-\mathbf{K b}$

A imagem cuja data não pôde ser identificada foi arranjada considerando características históricas, tais como personagens que compõe a imagem, lugares registrados, vestimentas e demais características, de acordo com a documentação biográfica de Paulo Freire. Salientamos ainda que, em algumas imagens, não nos foi possível identificar os nomes, locais (espaço), deixando dúvidas, o que nos obrigou a adotar como procedimento a categoria não-determinado, representado pela sigla ND (em letras minúsculas, sem espaço entre as letras). Outros padrões de notação foram adotados com objetivo de diferenciar determinados registros ou referências de cada documento imagético, estas notações foram assim determinadas:

* Para informações adquiridas através da pesquisa e acrescidas as descrições, coloca-se entre colchetes [ ].

* Para informações acrescidas, mas ainda com algumas dúvidas, acrescenta-se no colchete um sinal de interrogação [ ?]

* Para informações que não foi possível identificação, utilizam-se apenas o colchete e a interrogação [?]

\section{CONSIDERAÇÕES FINAIS}

A proposta de uma sistematização para o acervo imagético da BDPF pode ser descrita como o processo que deve levar em conta os aspectos estéticos, técnicos e cronológicos da imagem, para melhor dimensionamento do acervo e possibilidade de acesso. O conjunto das informações agregadas a esses suportes pode ser assim identificado com os aspectos estéticos: a temática, descrição e colorido da imagem. Para os aspectos técnicos, observam-se o formato da imagem, seu tamanho, peso e definição, e o cronológico restringe-se à data que possa ser recuperada, mesmo que aproximada.

E, por fim, a imagem pode ser remetida de acordo com o interesse do usuário e as relações temáticas a serem estabelecidas. A partir dos atributos identificados e descriminados neste estudo, serão selecionados descritores para as imagens, utilizando-se para isso o vocabulário, controlado ou natural, que estiver sendo empregado para a totalidade dos documentos da BDPF. Assim, os elementos que foram indicados como atributos de organização e sistematização desse acervo devem contribuir para o eficiente e rápido tratamento e disponibilização dessas informações.

Artigo recebido em 10-09-2004 e aceito para publicação em 29-03-2005.

\section{REFERÊNCIAS}

ALVES, Mônica C.; VALÉRIO, Sergio A. Manual de indexação de documentos fotográficos, Rio de Janeiro : Fundação Biblioteca Nacional, 1998.

AZEVEDO NETTO, Carlos X. de. A natureza da informação da arte rupestre: a proximidade de dois campos. Informare - Cadernos do Programa de Pós-graduação em Ciência da Informação, Rio de Janeiro, v. 4, n. 2, 1998, p. 55-62.

AUMONT, Jacques. A imagem. Campinas : Papirus, 1995.

BECKER, Howard S. Métodos de pesquisa em ciências sociais. Tradução de Marco Estevão e Renato Aguiar. São Paulo : HUCITEC, 1993. 230 p.

BENJAMIN, Walter. A obra de arte na época de reprodutibilidade técnica. In: ADORNO, T. et al. Teoria da cultura de massa. 3. ed. Rio de Janeiro : Paz e Terra, 1982, p. 209-242.

DAHLBERG, Ingetraut. Ontical structure and universal classifications. Bangalore : Sarada Ranganathan Endowment for Library Science, 1978a. $64 \mathrm{p}$.

. Teoria do conceito. Ciência da Informação, Brasília, v. 7, n. 2, 1978b, p. 101-107.

ECO, Umberto. Semiótica e filosofia da linguagem. São Paulo : Ática, 1991.

Tratado geral de semiótica. São Paulo : Perspectiva, 1980.

FOSKETT, Antony C. A abordagem temática da informação. São Paulo : Polígono, 1973.

GUATTARI, Félix. Caosmose: o novo paradigma estético. São Paulo : Ed. 34, 1998.

GOMBRICH, Ernst Hans. Arte e ilusão: um estudo da psicologia da representação pictórica. 3. ed. São Paulo : Martins Fontes, 1995.

HORLAND, B.; ALBRECHTSEN, Hanns. Toward a new horizon in information science: domain analysis. Journal of the American Society of Information Science, n. 46, v. 6, 1995, p. 400-425.

INSTITUTO NACIONAL DE PESQUISAS EDUCACIONAIS. Thesaurus brasileiro de educação. Disponível em: <http://www.inep.gov.br./pesquisa/ thesaurus $>$.

JAENECKE, Peter. To what end knowledge? Knowledge Organization, n. 21, v. 1, 1994, p. 3-11.

JEUDY, Henri-Pierre. Memórias do social. Rio de Janeiro : Forense Universitária, 1990.

Ci. Inf., Brasília, v. 33, n. 3, p.17-25, set./dez. 2004 


\section{A representação de imagens no acervo da Biblioteca Digital Paulo Freire - proposta e percursos}

JOLY, Martine. Introdução à análise da imagem. Campinas : Papirus, 1996.

LANGRIDGE, Derek. Classificação: abordagem para estudantes de biblioteconomia, Rio de Janeiro : Interciência, 1977.

LUCENA, Márcia Yoko Nishio. A imagem infográfica: uma imagem acontecimento. 2002. Dissertação (Mestrado em Artes Visuais) Universidade Federal do Rio de Janeiro, Rio de Janeiro, 2002.

MARIN, Louis. A Descrição da imagem: a propósito de uma paisagem de Poussin. In: METZ, C. et al. Análise das imagens. Petrópolis : Vozes, 1974, p. 82-121.

MOLES, Abraham. Doutrinas sobre a comunicação de massas. In: ADORNO, T. et al. Teoria da cultura de massa. 3. ed. Rio de Janeiro : Paz e Terra, 1982, p. 73-102.

PANOFSKY, E. Significado das artes visuais. 2. ed. São Paulo : Perspectiva, 1979. (Debates, n. 99).

PEIRCE, C. S. Semiótica. São Paulo : Perspectiva, 1985.
PIEDADE, M. A. Requião. Introdução à teoria da classificação. Rio de Janeiro : Interciência, 1977.

SANTAELLA, Lúcia; NÖTH, Winfried. Imagem: cognição, semiótica, mídia. São Paulo : Iluminuras, 1998.

SCHEFER, Jean-Louis. A imagem: o sentido investido. In: METZ, C. et al. Análise das imagens. Petrópolis : Vozes, 1974, p. 82-121.

SILVA, Cássia M. M. Imagem x palavra: a recuperação da informação imagética. Interdiscursos da ciência da informação: arte, museu e imagem. Rio de Janeiro : IBICT/DEP, 2000.

SILVA, Rubens Ribeiro Gonçalves da. Digitalização de acervos fotográficos públicos e seus reflexos institucionais: tecnologia e consciência no universo digital. 2002. Tese (Doutorado em Ciência da Informação) - Universidade Federal do Rio de Janeiro/Instituto Brasileiro de Informação em Ciência e Tecnologia, Rio de Janeiro, 2002.

SMIT, Johanna W. A representação da imagem. Informare - Cadernos do Programa de Pós-graduação em Ciência da Informação, Rio de Janeiro, v. 2, n. 2, p. 28-36, 1996. 